\title{
Studi Komparasi Metode Entropy dan ROC dalam Menentukan Bobot Kriteria
}

\author{
COKRO EDI PRAWI RO, MUHAMMAD YUSRI L HELMI SETYAWAN, \\ SYAFRI AL FACHRI PANE
}

Program Studi D4 Teknik Informatika Politeknik Pos Indonesia, Indonesia

Email: cokroedi2@gmail.com

Received 07 September 2020 | Revised 18 Oktober 2020 | Accepted 23 Oktober 2020

\begin{abstract}
ABSTRAK
Bobot kriteria yang sangat penting dan berpengaruh pada hasil pengambilan keputusan perlu dicari metode untuk menentukan bobot yang tepat dalam menentukan kriteria. Pada penelitian ini dilakukan studi komparasi antara metode Entropy dan ROC untuk mencari metode dalam pembobotan kriteria yang sesuai untuk pengambilan keputusan. Pada penelitian ini dilakukan uji sensitivitas dan nilai efektif pada kriteria yang dijadikan parameter pembanding antara metode entropy dan ROC. Hasil dari penelitian ini uji sensitivitas untuk metode ROC mendapatkan nilai sebesar 2,98752381 Sedangkan entropy 1,406581327 dan untuk uji nilai efektif pada metode ROC semua kriteria efektif sedangkan metode entropy dua kriteria efektif dan tiga kriteria tidak efetif. Berdasarkan hasil tersebut metode ROC lebih baik dalam menentukan bobot kriteria untuk pengambilan keputusan.
\end{abstract}

Kata kunci: Bobot, ROC, Entropy, Sensitivitas, Efektif

\section{ABSTRACT}

The weight of the criterion which is very important and has an effect on the results of decision making, it is necessary to find a method to determine the appropriate weight in determining the criteria. In this study, a comparative study was carried out between the Entropy and ROC methods to find a method of weighting the appropriate criteria for decision making. In this study, the sensitivity and effective value of the criteria were tested as parameters of comparison. The results of the sensitivity test for the ROC method obtained a value of 2.98752381 while the entropy was 1.406581327 and for the effective value test on the ROC method, all criteria were effective while the entropy method was effective with two criteria and three criteria were ineffective. Based on these results the ROC method is better at determining the weight of the criteria for decision makers.

Keywords: Weight, ROC, Entropy, sensitivity, Effective 


\section{PENDAHULUAN}

Dalam menentukan keputusan biasanya terdapat beberapa kriteria dengan tingkat kepentingan yang berbeda-beda, kriteria tersebut sangat berpengaruh pada hasil dari pengambilan keputusan, tingkat kepentingan dari kriteria tersebut bisa berupa nilai bobot. Dalam menentukan nilai bobot kriteria tersebut terdapat beberapa cara atau metode, salah satunya dengan menggunakan metode untuk menentukan bobot kriteria dengan cara rangking (Sureeyatanapas, 2016), selain dengan cara rangking, juga dapat dengan menggunakan metode yang termasuk pada MCDM (Multi Criterion Decision Making) (Odu, 2019) (Tunggal \& Budi, 2020). Adapun yang disebut sebagai bobot kriteria merupakan nilai yang terdapat pada kriteria biasanya berupa angka yang dibagi dari nilai 1 atau $100 \%$ yang menjadi nilai pembeda antara kriteria yang satu dengan kriteria yang lainnya.

Untuk menentukan bobot kriteria dalam mengambil keputusan atau pada sistem pengambil keputusan dapat menggunakan metode entropy, metode tersebut dapat digunakan untuk menentukan bobot kriteria pada pengambilan keputusan (Harapah, dkk, 2017). Dalam menentukan bobot kriteria dengan menggunakan metode entropy ini biasanya terpengaruh oleh data alternatif yang digunakan untuk mengambil keputusan, sehingga jika terjadi perubahan pada data alternatif maka nilai bobot menggunakan metode entropy ini akan berubah, hal tersebut menjadi permasalahan karena jika data bobot kriteria yang digunakan untuk mengambil keputusan berubah akan berpengaruh pada hasil keputusan yang berubah (Pamučar, dkk, 2018). Karena itu peranan bobot kriteria sangat penting terhadap hasil pengambilan keputusan (Toloie-Eshlaghy \& Farokhi, 2011), untuk mencari solusi dalam menentukan bobot kriteria tersebut maka dilakukan studi komparasi antara metode entropy dengan metode ROC studi komparasi antara kedua metode tersebut dilakukan karena metode entropy dan ROC merupakan metode yang digunakan untuk menentukan bobot kriteria selain itu dengan melakukan studi komparasi dapat diketahui metode yang cocok untuk menentukan bobot kriteria.

Studi komparasi merupakan penelitian yang melakukan perbandingan baik itu mengenai persamaan maupun perbedaan yang dilakukan berdasarkan kerangka pemikiran tertentu (Kolios, dkk, 2016). Adapun arti lain dari studi komparasi merupakan suatu metode atau cara yang digunakan untuk membandingkan data-data yang ditarik ke dalam kesimpulan baru (Kusuma, dkk, 2019). Pada penelitian ini studi komparasi yang dilakukan yaitu perbandingan antara metode entropy dengan metode ROC (Rank Order Centroid) kedua metode tersebut digunakan untuk menentukan bobot kriteria pada sistem pendukung keputusan (Windia Ambarsari, dkk, 2019).

Adapun metode ROC ini di pilih untuk dilakukan komparasi dengan metode Entropy karena metode tersebut merupakan metode yang digunakan untuk menentukan bobot kriteria (Maulachela, dkk, 2019). Selain itu metode ROC juga mudah di aplikasikan pada sistem pengambilan keputusan adapun dalam implementasi metode ROC harus dilakukan penentuan tingkat kepentingan dari setiap kriteria oleh pengambil keputusan (Sudipa \& Aryati, 2019). Kemudian untuk penentuan prioritas pada metode ROC dapat dilakukan dengan cara memilih terlebih dahulu kriteria yang paling prioritas atau dengan menentukan tingkat kepentingan dari setiap kriteria contoh seperti kriteria ke 1 lebih penting daripada kriteria ke 2 dan seterusnya sampai ditentukannya kriteria paling prioritas hingga kriteria yang tidak terlalu prioritas hal ini mencakup semua kriteria yang digunakan dalam pengambilan keputusan (Tangkesalu \& Suseno, 2018).

Dengan dilakukannya studi komparasi antara metode entropy dengan metode ROC dalam menentukan bobot kriteria. Hasil dari penelitian ini dapat mengetahui efektivitas antara 
metode entropy dan metode ROC dalam menentukan bobot kriteria yang digunakan pada pengambilan keputusan salah satunya seperti promethee. Sehingga dapat diketahui metode yang sesuai untuk di implementasikan untuk pengambilan keputusan dengan kasus yang mirip seperti pada penelitian ini.

\section{METODE}

\subsection{Metode Entropy}

Metode entropy merupakan metode yang termasuk dalam model MCDM (Multi Criterion Decision Making) (Hussain, dkk, 2017). Metode entropy juga cukup kuat dalam menghitung bobot dari kriteria. Dengan menggunakan metode entropy peneliti dapat menentukan bobot (tingkat kepentingan) awal dari setiap kriteria (Sai \& Babu, 2017). Kemudian dengan menggunakan metode entropy dapat menormalisasi nilia-nilai pada setiap kriteria walaupun memiliki perbedaan satuan baik itu kualitatif maupun kuantitatif, serta perbedaan jarak nilai yang terdapat pada alternatif (Suryani \& I mrona, 2012). Kemudian untuk persamaan dari metode entropy itu sendiri seperti Persamaan (1) berikut:

$$
H_{i}=-h_{o} \sum_{j=1}^{m} P_{i j} \cdot \ln P_{i j} \quad, i=1, \ldots, n
$$

Adapun penjelasan dari Persamaan (1) tersebut seperti berikut:

1. $H_{i}$ merupakan nilai entropy awal.

2. $-h_{o}$ merupakan nilai dari hasil pembagian $\frac{-1}{\ln \text { (Jumlah Alternatif })}$.

3. $P_{i j}$ merupakan nilai hasil normalisasi data alternatif.

Kemudian untuk Persamaan normalisasi data alternatif seperti Persamaan (2) berikut:

$$
P_{i j}=\frac{X_{i j}}{\sum_{j=1}^{m} X_{i j}}, j=1, \ldots, m, i=1, \ldots, n
$$

Adapun penjelasan dari Persamaan (2) tersebut seperti berikut:

1. $P_{i j}$ adalah nilai normalisasi untuk setiap kolom atau hanya satu kolom pada tabel.

2. $X_{i j}$ adalah nilai yang terdapat pada setiap kolom tabel kriteria dan alternatif.

3. $\sum_{j=1}^{m} X_{i j}$ merupakan nilai total dari setiap baris kriteria dan kolom alternatif.

Terakhir untuk menentukan nilai bobot kriteria dari metode entropy menggunakan Persamaan (3) berikut:

$$
\mathrm{W}=\frac{d_{i}}{\sum_{j=1}^{m} d_{i}}, i=1, \ldots, n
$$

Kemudian untuk penjelasan dari Rumus (3) tersebut seperti berikut:

1. W merupakan bobot akhir dari entropy.

2. $d_{i}$ merupakan nilai hasil pengurangan antara $1-h_{i}$.

3. $\sum_{j=1}^{m} d_{i}$ merupakan nilai total dari $d_{i}$.

\subsection{Metode ROC (Rank Order Centroid)}

Metode ROC (Rank Order Centroid) merupakan metode yang dapat memberikan bobot pada setiap kriteria sesuai dengan rangking yang dinilai berdasarkan tingkat kepentingan. Adapun 
biasanya dalam menentukan tingkat kepentingan dengan membentuk pernyataan "Kriteria 1 lebih penting dari kriteria 2, kriteria 2 lebih penting daripada kriteria 3 dan seterusnya hingga kriteria ke $\mathrm{n}^{\prime \prime}$ atau jika di bentuk dalam simbol seperti berikut $\mathrm{Cr} 1>\mathrm{Cr} 2>\mathrm{Cr} 3>\cdots>\mathrm{Crn}$ (Lubis, dkk, 2020). Kemudian untuk menentukan bobotnya yaitu bobot ke-1 mewakili kriteria ke-1 (Sureeyatanapas, dkk, 2018). Lalu untuk Rumus dari metode ROC itu sendiri seperti pada Persamaan (4) berikut:

$$
W_{n}=\frac{1}{m} \sum_{1=1}^{m}\left(\frac{1}{i}\right)
$$

Adapun penjelasan dari Persamaan (4) tersebut seperti berikut:

1. $W_{n}$ merupakan nilai bobot ROC.

2. $m$ merupakan banyaknya kriteria.

3. $\sum_{1=1}^{m}\left(\frac{1}{i}\right)$ merupakan nilai total dari pembagian nilai untuk setiap kriteria.

4. $i$ merupakan urutan dari prioritas.

\subsection{Analisis dan Perancangan Perbandingan}

Analisis yang dilakukan digunakan untuk membandingkan metode entropy dengan metode ROC, adapun poin-poin atau variabel-variabel yang digunakan untuk perbandingan antara metode entropy dan metode ROC yaitu:

1. Membandingkan Nilai sensitivitas yang diambil dari kombinasi metode entropy dengan metode promethee dan metode ROC dengan metode promethee.

2. Membandingkan nilai efektif dari setiap kriteria pada metode entropy maupun metode ROC.

Adapun untuk data yang digunakan untuk uji sensitivitas dan untuk mencari bobot kriteria yang digunakan untuk membandingkan data bobot kriteria dari segi nilai efektif seperti pada Tabel 1 berikut:

Tabel 1. Data Alternatif dan Kriteria

\begin{tabular}{|c|c|c|c|c|c|}
\hline Nama Alternatif & Kriteria & Kriteria & Kriteria & Kriteria & Kriteria \\
\hline Operasi 1 & $\mathbf{2}$ & $\mathbf{2}$ & $\mathbf{3}$ & $\mathbf{4}$ & $\mathbf{5}$ \\
\hline Operasi 2 & 3 & 5 & 2 & 0,1 & 0,4 \\
\hline Operasi 3 & 4 & 3 & 2 & 0,1 & 0,1 \\
\hline Operasi 4 & 3 & 4 & 2 & 0,3 & 0,1 \\
\hline Operasi 5 & 3 & 4 & 2 & 0,1 & 0,1 \\
\hline Operasi 6 & 3 & 3 & 2 & 0,4 & 0,2 \\
\hline Operasi 7 & 2 & 4 & 2 & 0,3 & 0,1 \\
\hline Operasi 8 & 1 & 2 & 22 & 0,9 & 0,1 \\
\hline Operasi 9 & 2 & 4 & 2 & 0,1 & 0,5 \\
\hline Operasi 10 & 3 & 4 & 1 & 0,3 & 0,2 \\
\hline Operasi 11 & 3 & 4 & 1 & 0,1 & 0,1 \\
\hline Operasi 12 & 1 & 4 & 26 & 0,7 & 0,2 \\
\hline Operasi 13 & 3 & 3 & 2 & 0,1 & 0,2 \\
\hline Operasi 14 & 3 & 3 & 2 & 0,1 & 0,2 \\
\hline Operasi 15 & 2 & 3 & 2 & 0,1 & 0,3 \\
\hline
\end{tabular}

Data yang terdapat pada Tabel 1 tersebut merupakan perumpamaan data yang digunakan untuk menentukan urutan pekerjaan pada sebuah produksi benda data tersebut hanya sebagai 
pemisalan, pada Tabel 1 tersebut terdapat 15 alternatif terdiri dari operasi 1 sampai operasi 15 yang masing-masing mewakili satu kegiatan produksi, data alternatif pada Tabel 1 tersebut belum ditentukan urutan pengerjaannya maka dari itu dengan menggunakan data tersebut dilakukan perhitungan secara matematis menggunakan metode entropy-promethee dan ROCpromethee untuk menentukan urutan dari pengerjaan alternatif yang di pengaruhi oleh lima kriteria yang terdiri dari kriteria 1 sebagai tingkat urgensi, kriteria 2 waktu mulai pekerjaan, kriteria 3 Quantity, kriteria 4 merupakan waktu penyiapan, dan kriteria 5 merupakan waktu standar, berdasarkan hasil urutan pengerjaan alternatif tersebut dilakukan uji sensitivitas terhadap metode entropy dan ROC. Kemudian dengan data yang terdapat pada Tabel 1 tersebut juga didapatkan bobot kriteria menggunakan metode entropy yang digunakan untuk menguji nilai efektif dari bobot kriteria.

\subsection{Mencari Nilai Sensitivitas}

Umumnya sensitivitas merupakan tingkat kepekaan terhadap suatu reaksi, untuk sensitivitas pada penelitian ini merupakan tingkat kepekaan metode untuk mencari keputusan dengan menggunakan bobot kriteria yang telah didapatkan dari hasil perhitungan metode entropy dan ROC Mencari nilai sensitivitas atau menguji nilai sensitivitas merupakan proses untuk mengetahui serta mendapatkan hasil dari perbandingan antara metode Entropy dan metode ROC, adapun uji sensitivitas ini dilakukan pada metode promethee sehingga menjadi kombinasi antara metode entropy dengan promethee dan kombinasi metode ROC dengan promethee, uji sensitivitas ini dilakukan pada penelitian ini untuk mengetahui tingkat sensitif dari metode tersebut, semakin sensitif nilai yang diperoleh dari setiap perubahan hasil metode maka metode yang memiliki sensitivitas tinggi merupakan metode yang akan dipilih (Fernando \& Handayani, 2018).

Nilai sensitivitas dapat diperoleh melalui langkah-langkah seperti berikut:

1. Cari terlebih dahulu bobot kriteria menggunakan metode entropy dan metode ROC

2. Normalisasi bobot kriteria yang telah didapatkan sehingga menghasilkan nilai total sama dengan 1 (satu)

3. Aplikasikan bobot tersebut pada metode promethee sehingga mendapat hasil urutan dari metode promethee tersebut

4. Hitung selisih perubahan urutan dari hasil perhitungan menggunakan metode promethee dengan cara membandingkan nilai maksimal pada saat bobot total sama dengan 1 (satu).

\subsection{Mencari Nilai Efektif Dari Kriteria}

Nilai efektif merupakan nilai yang lebih baik atau sama dengan nilai target, pada penelitian ini nilai target merupakan bobot awal kriteria. Kemudian untuk mencari nilai efektif dari kriteria dapat dilakukan dengan cara mencari data dari nilai bobot kriteria kemudian dicari efektivitas dari nilai bobot kriteria tersebut, lalu mengelompokkan kriteria yang termasuk efektif dan tidak efektif baik itu hasil perhitungan Entropy maupun ROC (Setiawan, Dani E;Mais, 2017). Kemudian untuk tahapan perbandingan dalam mencari nilai efektif dari kriteria seperti berikut:

1. Kemudian setelah melakukan normalisasi data, maka dilakukan perhitungan bobot menggunakan metode entropy dan ROC.

2. Maka setelah mendapatkan bobot kriteria dari perhitungan menggunakan entropy dan ROC yang pertama, maka lakukan kembali untuk mencari bobot yang kedua dengan catatan data alternatif harus diperbaharui.

3. Setelah data bobot pertama dan kedua telah didapatkan maka dilanjutkan perhitungan untuk mencari nilai efektif dari setiap kriteria dengan ketentuan seperti berikut :

Efektivitas = output aktual / output target 
Kemudian untuk penerapannya dalam mengukur nilai efektif dari bobot kriteria yaitu seperti berikut:

a. Output target $=$ bobot dari perhitungan entropy dan ROC awal.

b. Output aktual = bobot entropy dan ROC dari data yang telah di perbaharui. Kemudian untuk menentukan efektif dan tidak efektif, aturannya seperti berikut :

a. Apabila hasil pembagian antara output aktual dengan output target $<1$ (lebih kecil dari 1) maka dinyatakan tidak efektif.

b. Apabila hasil pembagian antara output aktual dengan output target $>=1$ (lebih besar sama dengan 1) maka dinyatakan efektif.

4. Kemudian setelah melakukan perhitungan untuk mencari nilai efektif dari setiap kriteria maka didapatkan nilai efektif dan tidak efektif dari bobot kriteria yang dihasilkan oleh metode Entropy dan bobot kriteria yang dihasilkan oleh metode ROC.

\section{HASI L DAN PEMBAHASAN}

\subsection{Mencari Nilai Sensitivitas Dari Kriteria}

Untuk melakukan uji sensitivitas diperlukan data hasil perhitungan secara matematis menggunakan metode entropy-promethee dan ROC-promethee yang menggunakan data alternatif dan kriteria yang terdapat pada Tabel 1, Adapun untuk data hasil dari perhitungan matematik menggunakan perpaduan metode entropy dengan promethee dan hasil perpaduan antara metode ROC dengan promethee mendapatkan hasil nilai pada setiap alternatif seperti pada Tabel 1 berikut:

Tabel 2. Data Hasil Perhitungan Metode Entropy-Promethee dan ROC-Promethee

\begin{tabular}{|c|c|c|}
\hline Nama Alternatif & $\begin{array}{c}\text { Nilai Entropy - } \\
\text { Promethee }\end{array}$ & $\begin{array}{c}\text { Nilai ROC - } \\
\text { Promethee }\end{array}$ \\
\hline Operasi 1 & $-0,0343$ & 0,353779365 \\
\hline Operasi 2 & 0,020254 & $-0,077768254$ \\
\hline Operasi 3 & $-0,01896$ & 0,293065079 \\
\hline Operasi 4 & 0,026578 & 0,085326984 \\
\hline Operasi 5 & $-0,10392$ & 0,038451984 \\
\hline Operasi 6 & $-0,0456$ & $-0,101875397$ \\
\hline Operasi 7 & $-0,02033$ & 0,004523413 \\
\hline Operasi 8 & 0,080617 & $-0,383363492$ \\
\hline Operasi 9 & $-0,08258$ & $-0,015565873$ \\
\hline Operasi 10 & $-0,09525$ & 0,04379127 \\
\hline Operasi 11 & 0,00233 & 0,078612698 \\
\hline Operasi 12 & 0,351282 & 0,025934127 \\
\hline Operasi 13 & $-0,01147$ & $-0,08848254$ \\
\hline Operasi 14 & $-0,01147$ & $-0,08848254$ \\
\hline Operasi 15 & $-0,05718$ & $-0,167946825$ \\
\hline
\end{tabular}

Setelah mendapatkan nilai dari setiap alternatif seperti pada Tabel 2 tersebut maka selanjutnya dicari nilai maksimal masing-masing dari hasil perhitungan Entropy-Promethee dan ROCPromethee yang hasilnya seperti pada Tabel 3 berikut:

Tabel 3. Data Nilai Maksimum Metode Entropy-Promethee dan ROC-Promethee

\begin{tabular}{|c|c|}
\hline $\begin{array}{c}\text { Nilai Maksimal Entropy } \\
\text { - Promethee }\end{array}$ & $\begin{array}{c}\text { Nilai Maksimal ROC - } \\
\text { Promethee }\end{array}$ \\
\hline 0,351281846 & 0,353779365 \\
\hline
\end{tabular}


Kemudian untuk bobot entropy dan bobot ROC pada kriteria yang digunakan untuk mendapatkan nilai yang terdapat pada Tabel 2 tersebut menggunakan bobot kriteria pada Tabel 4 berikut ini:

Tabel 4. Data Bobot metode Entropy dan ROC

\begin{tabular}{|c|c|c|c|c|c|}
\hline Nama Metode & Kriteria 1 & Kriteria 2 & Kriteria 3 & Kriteria 4 & Kriteria 5 \\
\hline Entropy & 0,052215 & 0,017709 & 0,565792 & 0,24585 & 0,118434 \\
\hline ROC & 0,256667 & 0,456667 & 0,156667 & 0,09 & 0,04 \\
\hline
\end{tabular}

Dalam melakukan uji sensitivitas ini nilai bobot pada Tabel 4 tersebut dinaikkan sebesar 0,5 dan 1 hal ini dilakukan pada masing-masing nilai bobot kriteria dimulai dari kriteria ke 1 sampai kriteria ke 5, maka dari itu untuk bobot kriteria yang digunakan untuk uji sensitivitas pada kriteria 1 seperti pada Tabel 5 dan Tabel 6 seperti berikut:

Tabel 5. Data Bobot metode Entropy dan ROC Kriteria $1(+0,5)$

\begin{tabular}{|c|c|c|c|c|c|}
\hline Nama Metode & Kriteria 1 & Kriteria 2 & Kriteria 3 & Kriteria 4 & Kriteria 5 \\
\hline Entropy & 0,552215 & 0,017709 & 0,565792 & 0,24585 & 0,118434 \\
\hline ROC & 0,756666667 & 0,456667 & 0,156667 & 0,09 & 0,04 \\
\hline
\end{tabular}

Tabel 6. Data Bobot metode Entropy dan ROC Kriteria 1 (+1)

\begin{tabular}{|c|c|c|c|c|c|}
\hline Nama Metode & Kriteria 1 & Kriteria 2 & Kriteria 3 & Kriteria 4 & Kriteria 5 \\
\hline Entropy & 1,052215 & 0,017709 & 0,565792 & 0,24585 & 0,118434 \\
\hline ROC & 1,256666667 & 0,456667 & 0,156667 & 0,09 & 0,04 \\
\hline
\end{tabular}

Dari data pada Tabel 4 dan Tabel 5 tersebut dilakukan perhitungan kembali menggunakan metode entropy-promethee dan ROC-promethee dengan data alternatif menggunakan data yang terdapat pada Tabel 1 sehingga mendapatkan urutan prioritas baru dari setiap alternatif, dari urutan baru tersebut kemudian dicari kembali nilai maksimal dari nilai alternatif, sehingga mendapatkan nilai maksimal seperti pada Tabel 7 berikut:

Tabel 7. Data Nilai Maksimum Metode Entropy-Promethee dan ROC-Promethee Kriteria 1

\begin{tabular}{|c|c|c|c|}
\hline $\begin{array}{c}\text { Nilai Max Entropy- } \\
\text { Promethee + 0,5 }\end{array}$ & $\begin{array}{c}\text { Nilai Max ROC - } \\
\text { Promethee +0,5 }\end{array}$ & $\begin{array}{c}\text { Nilai Max Entropy- } \\
\text { Promethee + 1 }\end{array}$ & $\begin{array}{c}\text { Nilai Max ROC - } \\
\text { Promethee + 1 }\end{array}$ \\
\hline 0,269276156 & 0,657350794 & 0,572847585 & 0,960922222 \\
\hline
\end{tabular}

Kemudian untuk melakukan uji sensitivitas pada kriteria 2 maka dilakukan penambahan nilai bobot pada kriteria 2 tersebut sebesar 0,5 dan 1, untuk data bobot kriteria yang digunakan untuk uji sensitivitas pada kriteria 2 baik itu menggunakan metode entropy maupun ROC seperti pada Tabel 8 dan 9 berikut:

Tabel 8. Data Bobot metode Entropy dan ROC Kriteria $2(+0,5)$

\begin{tabular}{|c|c|c|c|c|c|}
\hline Nama Metode & Kriteria 1 & Kriteria 2 & Kriteria 3 & Kriteria 4 & Kriteria 5 \\
\hline Entropy & 0,052215 & 0,517709 & 0,565792 & 0,24585 & 0,118434 \\
\hline ROC & 0,256667 & 0,9566667 & 0,156667 & 0,09 & 0,04 \\
\hline
\end{tabular}


Tabel 9. Data Bobot metode Entropy dan ROC Kriteria $2(+1)$

\begin{tabular}{|c|c|c|c|c|c|}
\hline Nama Metode & Kriteria 1 & Kriteria 2 & Kriteria 3 & Kriteria 4 & Kriteria 5 \\
\hline Entropy & 0,052215 & 1,017709 & 0,565792 & 0,24585 & 0,118434 \\
\hline ROC & 0,256667 & 1,4566667 & 0,156667 & 0,09 & 0,04 \\
\hline
\end{tabular}

Dengan menggunakan data bobot kriteria pada Tabel 8 dan Tabel 9 tersebut dilakukan perhitungan secara matematis menggunakan metode promethee dengan menggunakan data alternatif dan kriteria pada Tabel 1 sehingga mendapatkan urutan pengerjaan alternatif baru, dari data tersebut dicari nilai maksimum sehingga mendapatkan hasil seperti pada Tabel 10:

Tabel 10. Data Nilai Maksimum Metode Entropy-Promethee dan ROC-Promethee Kriteria 2

\begin{tabular}{|c|c|c|c|}
\hline $\begin{array}{c}\text { Nilai Max Entropy- } \\
\text { Promethee + 0,5 }\end{array}$ & $\begin{array}{c}\text { Nilai Max ROC - } \\
\text { Promethee +0,5 }\end{array}$ & $\begin{array}{c}\text { Nilai Max Entropy- } \\
\text { Promethee + 1 }\end{array}$ & $\begin{array}{c}\text { Nilai Max ROC - } \\
\text { Promethee +1 }\end{array}$ \\
\hline 0,410805656 & 0,591874603 & 0,470329465 & 0,829969841 \\
\hline
\end{tabular}

Setelah dilakukan uji sensitivitas pada kriteria 2 maka dilanjutkan pada kriteria 3 dengan cara menambahkan nilai bobot pada kriteria 3 sebesar 0,5 dan 1, untuk data bobot kriteria yang digunakan untuk uji sensitivitas pada kriteria 3 baik itu menggunakan metode entropy maupun ROC seperti pada Tabel 11 dan 12 berikut:

Tabel 11. Data Bobot metode Entropy dan ROC Kriteria $3(+0,5)$

\begin{tabular}{|c|c|c|c|c|c|}
\hline Nama Metode & Kriteria 1 & Kriteria 2 & Kriteria 3 & Kriteria 4 & Kriteria 5 \\
\hline Entropy & 0,052215 & 0,017709 & 1,065792 & 0,24585 & 0,118434 \\
\hline ROC & 0,256667 & 0,456667 & 0,656667 & 0,09 & 0,04 \\
\hline
\end{tabular}

Tabel 12. Data Bobot metode Entropy dan ROC Kriteria $3(+1)$

\begin{tabular}{|c|c|c|c|c|c|}
\hline Nama Metode & Kriteria 1 & Kriteria 2 & Kriteria 3 & Kriteria 4 & Kriteria 5 \\
\hline Entropy & 0,052215 & 0,017709 & 1,565792 & 0,24585 & 0,118434 \\
\hline ROC & 0,256667 & 0,456667 & 1,156667 & 0,09 & 0,04 \\
\hline
\end{tabular}

Dengan menggunakan data bobot kriteria pada Tabel 11 dan Tabel 12 tersebut dilakukan perhitungan secara matematis menggunakan metode promethee dengan menggunakan data alternatif dan kriteria pada Tabel 1 sehingga mendapatkan urutan pengerjaan alternatif baru, dari data tersebut dicari nilai maksimum sehingga mendapatkan hasil seperti pada Tabel 13:

Tabel 13. Data Nilai Maksimum Metode Entropy-Promethee dan ROC-Promethee Kriteria 3

\begin{tabular}{|c|c|c|c|}
\hline $\begin{array}{c}\text { Nilai Max Entropy- } \\
\text { Promethee + 0,5 }\end{array}$ & $\begin{array}{c}\text { Nilai Max ROC - } \\
\text { Promethee +0,5 }\end{array}$ & $\begin{array}{c}\text { Nilai Max Entropy- } \\
\text { Promethee + 1 }\end{array}$ & $\begin{array}{c}\text { Nilai Max ROC - } \\
\text { Promethee +1 }\end{array}$ \\
\hline 0,80556756 & 0,480219841 & 1,259853275 & 0,934505556 \\
\hline
\end{tabular}

Setelah dilakukan uji sensitivitas pada kriteria 3 maka dilanjutkan pada kriteria 4 dengan cara menambahkan nilai bobot pada kriteria 4 sebesar 0,5 dan 1, untuk data bobot kriteria yang digunakan pada uji sensitivitas pada kriteria 4 baik itu menggunakan metode entropy maupun ROC seperti pada Tabel 14 dan 15 berikut:

Tabel 14. Data Bobot metode Entropy dan ROC Kriteria $4(+0,5)$

\begin{tabular}{|c|c|c|c|c|c|}
\hline Nama Metode & Kriteria 1 & Kriteria 2 & Kriteria 3 & Kriteria 4 & Kriteria 5 \\
\hline Entropy & 0,052215 & 0,017709 & 0,565792 & 0,74585 & 0,118434 \\
\hline ROC & 0,256667 & 0,456667 & 0,156667 & 0,59 & 0,04 \\
\hline
\end{tabular}


Tabel 15. Data Bobot metode Entropy dan ROC Kriteria $4(+1)$

\begin{tabular}{|c|c|c|c|c|c|}
\hline Nama Metode & Kriteria 1 & Kriteria 2 & Kriteria 3 & Kriteria 4 & Kriteria 5 \\
\hline Entropy & 0,052215 & 0,017709 & 0,565792 & 1,24585 & 0,118434 \\
\hline ROC & 0,256667 & 0,456667 & 0,156667 & 1,09 & 0,04 \\
\hline
\end{tabular}

Dengan menggunakan data bobot kriteria pada Tabel 14 dan Tabel 15 tersebut dilakukan perhitungan secara matematis menggunakan metode promethee dengan menggunakan data alternatif dan kriteria pada Tabel 1 sehingga mendapatkan urutan pengerjaan alternatif baru, dari data tersebut dicari nilai maksimum sehingga mendapatkan hasil seperti pada Tabel 16:

Tabel 16. Data Nilai Maksimum Metode Entropy-Promethee dan ROC-Promethee Kriteria 4

\begin{tabular}{|c|c|c|c|}
\hline $\begin{array}{c}\text { Nilai Max Entropy- } \\
\text { Promethee + 0,5 }\end{array}$ & $\begin{array}{c}\text { Nilai Max ROC - } \\
\text { Promethee +0,5 }\end{array}$ & $\begin{array}{c}\text { Nilai Max Entropy- } \\
\text { Promethee + 1 }\end{array}$ & $\begin{array}{c}\text { Nilai Max ROC - } \\
\text { Promethee + 1 }\end{array}$ \\
\hline 0,133721056 & 0,460922222 & 0,240863913 & 0,568065079 \\
\hline
\end{tabular}

Setelah dilakukan uji sensitivitas pada kriteria 4 maka dilanjutkan pada kriteria 5 dengan cara menambahkan nilai bobot pada kriteria 5 sebesar 0,5 dan 1, untuk data bobot kriteria yang digunakan pada uji sensitivitas pada kriteria 5 baik itu menggunakan metode entropy maupun ROC seperti pada Tabel 17 dan 18 berikut:

Tabel 17. Data Bobot metode Entropy dan ROC Kriteria $5(+0,5)$

\begin{tabular}{|c|c|c|c|c|c|}
\hline Nama Metode & Kriteria 1 & Kriteria 2 & Kriteria 3 & Kriteria 4 & Kriteria 5 \\
\hline Entropy & 0,052215 & 0,017709 & 0,565792 & 0,24585 & 0,618434 \\
\hline ROC & 0,256667 & 0,456667 & 0,156667 & 0,09 & 0,54 \\
\hline
\end{tabular}

Tabel 18. Data Bobot metode Entropy dan ROC Kriteria 5 (+1)

\begin{tabular}{|c|c|c|c|c|c|}
\hline Nama Metode & Kriteria 1 & Kriteria 2 & Kriteria 3 & Kriteria 4 & Kriteria 5 \\
\hline Entropy & 0,052215 & 0,017709 & 0,565792 & 0,24585 & 1,118434 \\
\hline ROC & 0,256667 & 0,456667 & 0,156667 & 0,09 & 1,04 \\
\hline
\end{tabular}

Dengan menggunakan data bobot kriteria pada Tabel 17 dan Tabel 18 tersebut dilakukan perhitungan secara matematis menggunakan metode promethee dengan menggunakan data alternatif dan kriteria pada Tabel 1 sehingga mendapatkan urutan pengerjaan alternatif baru, dari data tersebut dicari nilai maksimum sehingga mendapatkan hasil seperti pada Tabel 19:

Tabel 19. Data Nilai Maksimum Metode Entropy-Promethee dan ROC-Promethee Kriteria 5

\begin{tabular}{|c|c|c|c|}
\hline $\begin{array}{c}\text { Nilai Max Entropy- } \\
\text { Promethee + 0,5 }\end{array}$ & $\begin{array}{c}\text { Nilai Max ROC - } \\
\text { Promethee +0,5 }\end{array}$ & $\begin{array}{c}\text { Nilai Max Entropy- } \\
\text { Promethee + 1 }\end{array}$ & $\begin{array}{c}\text { Nilai Max ROC - } \\
\text { Promethee + 1 }\end{array}$ \\
\hline 0,369138989 & 0,444850794 & 0,386996132 & 0,596636508 \\
\hline
\end{tabular}


Tabel 20. Data Uji Sensitivitas Metode Entropy-Promethee

\begin{tabular}{|l|c|c|}
\hline $\begin{array}{c}\text { Nialai tambah } \\
\text { pada kriteria }\end{array}$ & Nilai maksimum & Selisih \\
\hline Kriteria $1=+0,5$ & 0,269276156 & $-0,08200569$ \\
\hline Kriteria $1=+1$ & 0,572847585 & 0,221565739 \\
\hline Kriteria 2 $=+0,5$ & 0,410805656 & 0,05952381 \\
\hline Kriteria 2 $=+1$ & 0,470329465 & 0,119047619 \\
\hline Kriteria 3 $=+0,5$ & 0,80556756 & 0,454285714 \\
\hline Kriteria 3 $=+1$ & 1,259853275 & 0,908571429 \\
\hline Kriteria 4 =+0,5 & 0,133721056 & $-0,21756079$ \\
\hline Kriteria 4 $=+1$ & 0,240863913 & $-0,110417933$ \\
\hline Kriteria 5 $=+0,5$ & 0,369138989 & 0,017857143 \\
\hline Kriteria 5 $=+1$ & 0,386996132 & 0,035714286 \\
\hline
\end{tabular}

Pada Tabel 20 tersebut dilakukan pengurangan dengan nilai maksimum hasil perhitungan metode entropy-promethee dengan nilai maksimum yang nilai kriterianya di tambah 0,5 dan 1 sehingga mendapatkan selisih, selisih tersebut di totalkan sehingga mendapatkan nilai total yang merupakan nilai sensitivitas sebesar 1,406581327. Lalu untuk data uji sensitivitas metode ROC-promethee seperti pada Tabel 21 berikut.

Tabel 21. Data Uji Sensitivitas Metode ROC-Promethee

\begin{tabular}{|l|c|c|}
\hline $\begin{array}{c}\text { Nialai tambah } \\
\text { pada kriteria }\end{array}$ & Nilai maksimum & Selisih \\
\hline Kriteria $1=+0,5$ & 0,657350794 & 0,303571429 \\
\hline Kriteria $1=+1$ & 0,960922222 & 0,607142857 \\
\hline Kriteria 2 $=+0,5$ & 0,591874603 & 0,238095238 \\
\hline Kriteria 2 $=+1$ & 0,829969841 & 0,476190476 \\
\hline Kriteria 3 = +0,5 & 0,480219841 & 0,126440476 \\
\hline Kriteria 3 $=+1$ & 0,934505556 & 0,580726191 \\
\hline Kriteria 4 $=+0,5$ & 0,460922222 & 0,107142857 \\
\hline Kriteria 4 $=+1$ & 0,568065079 & 0,214285714 \\
\hline Kriteria 5 $=+0,5$ & 0,444850794 & 0,091071429 \\
\hline Kriteria 5 $=+1$ & 0,596636508 & 0,242857143 \\
\hline
\end{tabular}

Untuk pengurangan pada Tabel 21 tersebut menggunakan nilai maksimum hasil metode ROCPromethee, adapun untuk nilai total dari selisih yang menjadi nilai sensitivitas dari metode ROC-Promethee sebesar 2,98752381.

\subsection{Uji Efektif Pada Kriteria}

Untuk melakukan uji efektif pada kriteria baik itu menggunakan metode entropy maupun ROC cari terlebih dahulu bobot pertama menggunakan metode entropy dan ROC, lalu setelah mendapatkan bobot pertama lakukan kembali perhitungan dengan data alternatif yang telah di perbaharui menggunakan metode entropy dan metode ROC, setelah itu bobot pertama dijadikan output target dan bobot kedua dijadikan bobot aktual, untuk bobot entropy awal didapatkan dari data alternatif pada Tabel 1 sehingga untuk bobot entropy awal seperti pada Tabel 22:

Tabel 22. Data Bobot Pertama metode Entropy

\begin{tabular}{|c|c|c|c|c|}
\hline Kriteria 1 & Kriteria 2 & Kriteria 3 & Kriteria 4 & Kriteria 5 \\
\hline 0,052215184 & 0,017708842 & 0,565791885 & 0,245849716 & 0,118434372 \\
\hline
\end{tabular}

Kemudian setelah itu lakukan perhitungan kedua menggunakan metode entropy untuk 
mendapatkan data bobot kriteria kedua, adapun untuk data alternatif yang digunakan untuk uji coba ini seperti pada Tabel 23 berikut:

Tabel 23. Data Alternatif Untuk Mencari Bobot Entropy kedua

\begin{tabular}{|c|c|c|c|c|c|}
\hline Nama Alternatif & Kriteria & Kriteria & Kriteria & Kriteria & Kriteria \\
\hline Operasi 1 & $\mathbf{1}$ & $\mathbf{2}$ & $\mathbf{3}$ & $\mathbf{4}$ & $\mathbf{5}$ \\
\hline Operasi 2 & 3 & 3 & 2 & 0,1 & 0,4 \\
\hline Operasi 3 & 4 & 3 & 2 & 0,1 & 0,1 \\
\hline Operasi 4 & 2 & 5 & 2 & 0,3 & 0,1 \\
\hline Operasi 5 & 2 & 4 & 2 & 0,1 & 0,1 \\
\hline Operasi 6 & 3 & 3 & 2 & 0,2 & 0,2 \\
\hline Operasi 7 & 2 & 4 & 2 & 0,3 & 0,1 \\
\hline Operasi 8 & 1 & 2 & 22 & 0,2 & 0,1 \\
\hline Operasi 9 & 2 & 3 & 2 & 0,1 & 0,5 \\
\hline Operasi 10 & 2 & 3 & 1 & 0,3 & 0,2 \\
\hline Operasi 11 & 3 & 4 & 1 & 0,1 & 0,1 \\
\hline Operasi 12 & 1 & 4 & 20 & 0,7 & 0,2 \\
\hline Operasi 13 & 3 & 3 & 2 & 0,1 & 0,2 \\
\hline Operasi 14 & 3 & 3 & 2 & 0,1 & 0,2 \\
\hline Operasi 15 & 2 & 3 & 2 & 0,1 & 0,3 \\
\hline
\end{tabular}

Dari data pada Tabel 23 tersebut didapatkan hasil bobot kedua menggunakan metode entropy yang hasilnya seperti pada Tabel 24 berikut:

Tabel 24. Data Bobot Ke Dua Metode Entropy

\begin{tabular}{|c|c|c|c|c|}
\hline Kriteria 1 & Kriteria 2 & Kriteria 3 & Kriteria 4 & Kriteria 5 \\
\hline 0,052993126 & 0,017253887 & 0,543361441 & 0,270185189 & 0,116206356 \\
\hline
\end{tabular}

Dari data pada Tabel 22 dan 24 tersebut dilakukan perhitungan untuk mencari nilai efektif kriteria dengan cara seperti berikut:

1. $0.052993126 / 0.052215184=1,014898764$ (efektif) (Kriteria 1)

2. $0.017253887 / 0.017708842=0,974309179$ (tidak efektif) (Kriteria 2)

3. $0.543361441 / 0.565791885=0,960355664$ (tidak efektif) (Kriteria 3)

4. $0.270185189 / 0.245849716=1,09898516$ (efektif) (Kriteria 4)

5. $0.116206356 / 0.118434372=0,981187761$ (tidak efektif) (Kriteria 5)

Dari hasil tersebut dapat diketahui bahwa kriteria 1 memiliki nilai 1,014898764 sehingga termasuk efektif, kriteria 2 memiliki nilai 0,974309179 sehingga termasuk tidak efektif, kriteria 3 memiliki nilai 0,960355664 sehingga termasuk tidak efektif, kriteria 4 memiliki nilai 1,09898516 sehingga termasuk efektif, kemudian terakhir kriteria 5 memiliki nilai 0,981187761 sehingga termasuk tidak efektif.

Kemudian setelah mendapatkan nilai efektif dan tidak efektif dari setiap bobot kriteria yang didapatkan dengan menggunakan metode entropy, selanjutnya dilanjutkan dengan mencari bobot kriteria dengan menggunakan metode ROC dengan cara menentukan tingkat kepentingan dari setiap kriteria, adapun untuk kepentingan kriterianya dengan aturan tingkat kepentingan sepertti berikut, Kriteria $2>$ Kriteria $1>$ Kriteria $3>$ Kriteria $4>$ Kriteria 5 , sehingga untuk pembagian bobotnya menjadi seperti berikut:

$\mathrm{W}($ Kriteria 1$)=1+1 / 2+1 / 3+1 / 4+1 / 5 / 5=0,456666667$ 
$W($ Kriteria 2$)=0+1 / 2+1 / 3+1 / 4+1 / 5 / 5=0,256666667$

$W($ Kriteria 3$)=0+0+1 / 3+1 / 4+1 / 5 / 5=0,156666667$

$W($ Kriteria 4$)=0+0+0+1 / 4+1 / 5 / 5=0,09$

$\mathrm{W}($ Kriteria 5$)=0+0+0+1 / 4+1 / 5 / 5=0,04$

Kemudian cari bobot ROC kedua dengan yang sama seperti cara untuk mencari bobot kriteria pertama menggunakan metode ROC seperti berikut:

$$
\begin{aligned}
& \mathrm{W}(\text { Kriteria } 1)=1+1 / 2+1 / 3+1 / 4+1 / 5 / 5=0,456666667 \\
& \mathrm{~W}(\text { Kriteria } 2)=0+1 / 2+1 / 3+1 / 4+1 / 5 / 5=0,256666667 \\
& \mathrm{~W}(\text { Kriteria 3) }=0+0+1 / 3+1 / 4+1 / 5 / 5=0,156666667 \\
& \mathrm{W}(\text { Kriteria 4) }=0+0+0+1 / 4+1 / 5 / 5=0,09 \\
& \mathrm{W}(\text { Kriteria } 5)=0+0+0+1 / 4+1 / 5 / 5=0,04
\end{aligned}
$$

Setelah mendapatkan nilai bobot pertama dan kedua dari metode ROC lakukan perhitungan untuk mencari nilai efektif kriteria dengan cara seperti berikut:
1. $0.456666667 / 0.456666667=1$ (efektif) (Kriteria 2)
2. $0.256666667 / 0.256666667=1$ (efektif) (Kriteria 1)
3. $0.156666667 / 0.156666667=1$ (efektif) (Kriteria 3)
4. $0.09 / 0.09=1$ (efektif) (Kriteria 4)
5. $0.04 / 0.04=1$ (efektif) (Kriteria 5)

\subsection{Hasil Nilai Sensitivitas dan Uji Efektif}

Dari hasil uji sensitivitas didapatkan hasil nilai sensitivitas untuk metode entropy-promethee sebesar 1,406581327 sedangkan nilai sensitivitas dari metode ROC-promethee sebesar 2,98752381, dari hasil tersebut maka dapat diketahui bahwa bobot kriteria hasil metode ROC yang diaplikasikan pada metode promethee lebih baik daripada bobot kriteria hasil metode entropy yang diaplikasikan pada metode promethee hal itu karena metode ROC-promethee memiliki nilai sensitivitas lebih besar daripada metode entropy-promethee. Kemudian dari hasil uji nilai efektif pada bobot kriteria yang dihasilkan oleh metode entropy mendapatkan hasil untuk bobot kriteria 1 dan kriteria 4 memiliki nilai efektif sedangkan untuk bobot kriteria 2, kriteria 3 dan kriteria 5 memiliki nilai tidak efektif, sehingga hasil dari uji nilai efektif pada bobot kriteria pada metode entropy secara keseluruhan yaitu dua kriteria memiliki nilai efektif dan tiga kriteria memiliki nilai tidak efektif. Adapun untuk uji nilai efektif pada bobot kriteria menggunakan metode ROC mendapatkan hasil untuk kriteria 1, kriteria 2, kriteria 3, kriteria 4, dan kriteria 5 semuanya memiliki nilai yang efektif, maka dari itu berdasarkan hasil tersebut dapat diketahui bahwa bobot kriteria yang dihasilkan oleh metode ROC semuanya bernilai efektif sehingga metode ROC lebih baik daripada metode entropy dalam menghasilkan bobot yang efektif untuk setiap kriteria.

\section{KESI MPULAN}

Dari hasil uji coba dan hasil pada uji sensitivitas dan pada uji nilai efektif kriteria yang digunakan sebagai parameter perbandingan antara metode entropy dengan metode ROC mendapatkan hasil uji sensitivitas metode ROC sebesar 2,98752381 sedangkan hasil uji sensitivitas untuk metode entropy sebesar 1,406581327 kemudian dari segi nilai efektif pada bobot kriteria yang dihasilkan oleh metode ROC dan entropy pada metode ROC sendiri semua bobot kriteria yang dihasilkan memiliki nilai yang efektif sedangkan untuk metode entropy terdapat dua kriteria yang memiliki nilai yang efektif dan tiga kriteria yang memiliki nilai tidak efektif, dari kedua hasil uji coba tersebut maka dapat disimpulkan bahwa metode ROC lebih efektif dalam menentukan bobot kriteria dalam pengambilan keputusan daripada metode 
Entropy karena dari segi sensitivitas dan nilai efektif dari bobot yang dihasilkan metode ROC lebih unggul dari pada metode entropy. Untuk hasil tersebut hanya berlaku pada pengambilan keputusan yang data alternatifnya berubah atau diperbaharui sehingga berpengaruh pada bobot kriteria.

\section{DAFTAR RUJ UKAN}

Fernando, D., \& Handayani, N. (2018). Uji Sensitivitas Metode Sistem Pendukung Keputusan Dalam Menentukan Lokasi Penyebaran Media Promosi. JSil (Jurnal Sistem Informasi), 5(2), 51-57.

Harapah, A. S., Tulus, \& Budhiarti, E. (2017). Penerapan Metode Entropy Dan Metode Promethee. Pelita Informatika, 16(3), 208-213.

Hussain, S. A. I., Mandal, U. kumar, \& Mondal, S. P. (2017). Entropy based MCDM approach for Selection of material. National Level Conference on Engineering Problems and Application of Mathematics, May 2016, 1-7.

Kolios, A., Mytilinou, V., Lozano-Minguez, E., \& Salonitis, K. (2016). A comparative study of multiple-criteria decision-making methods under stochastic inputs. Energies, 9(7), 121.

Kusuma, B. J., Karim, S., \& Mulyani, Y. (2019). Studi Perbandingan Kualitas Layanan Pantai Manggar dan Lamaru di Kota Balikpapan dengan Motode SERVQUAL. JSHP: Jurnal Sosial Humaniora Dan Pendidikan, 3(1), 29-38.

Lubis, A. I., Sihombing, P., \& Nababan, E. B. (2020). Comparison SAW and MOORA Methods with Attribute Weighting Using Rank Order Centroid in Decision Making. In 2020 3rd International Conference on Mechanical, Electronics, Computer, and Industrial Technology (MECnIT), 127-131.

Maulachela, A. B., Hidayat, S., Fitriani, N., Rizal, A. A., Budiarto, J., Anas, A. S., Nugraha, G. S., Juliansyah, A., Qudsi, J., Abdurahim, Yunus, M., \& Sriwinarti, N. K. (2019). Promethee: As a supporting decision of selection of poor rice receivers. Journal of Physics: Conference Series, 1211(1).

Odu, G. O. (2019). Weighting methods for multi-criteria decision making technique. Journal of Applied Sciences and Environmental Management, 23(8), 1449.

Pamučar, D., Stević, Ž., \& Sremac, S. (2018). A new model for determiningweight coefficients of criteria in MCDM models: Full Consistency Method (FUCOM). Symmetry, 10(9), 122.

Sai, N. V., \& Babu, K. P. (2017). An Integrated approach using VIKOR and ENTROPY methods for a Supplier selection problem. International Journal of Innovations in Engineering 
and Technology, 8(3), 1-9.

Setiawan, Dani E;Mais, A. (2017). Pengaruh Tingkat Kehadiran Siswa Terhadap Efektivitas Proses Pembelajaran Siswa Kelas IV Tunagrahita Ringan dalam Kelas Reguler SD Inklusi di Kabupaten Jember. Journal Of Special Education, 1, 28-33.

Sudipa, I. G. I., \& Aryati, K. S. (2019). Pendekatan Penentuan Bobot dengan Surrogate Weighting Procedures untuk Metode Simple Additive Weighting dalam Pengambilan Keputusan Multikriteria. 3(3), 113-121.

Sureeyatanapas, P. (2016). Comparison of rank-based weighting methods for multi-criteria decision making. KKU Engineering Journal. 43, 376-379.

Sureeyatanapas, P., Sriwattananusart, K., Niyamosoth, T., Sessomboon, W., \& Arunyanart, S. (2018). Supplier selection towards uncertain and unavailable information: An extension of TOPSIS method. Operations Research Perspectives, 5, 69-79.

Suryani, A. A., \& Imrona, M. (2012). Sistem pengambilan keputusan pemilihan bahan baku kain pada batik erza dengan metode entropy.

Tangkesalu, A. A., \& Suseno, J. E. (2018). Information System of Performance Assesment on Startup Business using Simple Multi-Attribute Rating Technique Exploiting Ranks (SMARTER). E3S Web of Conferences, 73, 2-6.

Toloie-Eshlaghy, A., \& Farokhi, E. N. (2011). Measuring the Importance and the Weight of Decision Makers in the Criteria Weighting Activities of Group Decision Making Process. American Journal of Scientific Research, 24(24), 6-12.

Tunggal, A., \& Budi, S. (2020). Pengambilan Keputusan Strategis Pemasaran di Perguruan Tinggi dengan menggunakan Analytics Hierarchy Process ( AHP ). Jurnal Teknik Informatika dan Sistem Informasi, 6.

Windia Ambarsari, E., Dhika, H., Juliana, Khotijah, S., \& Andri. (2019). Using weighted of ROC in analytical network process for decision making. Journal of Physics: Conference Series, 1175(1). 